\title{
Climate change impact assessment on three major crops in the north-central region of Bangladesh using DSSAT
}

\author{
Atikur Rahman $^{1 *}$, Mohammad Abdul Mojid ${ }^{1}$, Selina Banu ${ }^{2}$ \\ (1. Department of Irrigation and Water Management, Bangladesh Agricultural University, Mymensingh-2202, Bangladesh; \\ 2. Department of Agricultural and Industrial Engineering, Hajee Mohammad Danesh Science and Technology University, \\ Dinajpur-5200, Bangladesh)
}

\begin{abstract}
The potential consequences of climate change emanated from global warming are very alarming; the greatest concern is the potentially disastrous consequences on crop agriculture and food security in many parts of the world. Bangladesh is a country highly susceptible to climate change, but information in this regard is still inadequate. This study investigated the effects of climate change on three major crops - wheat, potato and rice - in the north-central region of Bangladesh. Two climate change scenarios, A2 and B2, of the Intergovernmental Panel on Climate Change (IPCC) were generated by employing MAGICC/SCENGEN model together with the observed climate data of the region. The growth and yield of the crops were simulated using DSSAT CERES-Wheat, SUBSTOR-Potato and CERES-Rice models under the present and projected future changing climatic conditions. For a predicted $5.32^{\circ} \mathrm{C}$ increase in temperature in the year 2100 , the yield of wheat, rice and potato would decrease by $47.6 \%, 67.8 \%$ and $38.6 \%$, respectively. The increased temperature would accelerate physiological maturity of the crops as reflected by their reduced length of growing season (LGS) by $1.20 \%$ to $18.5 \%$. The reduced LGS would reduce seasonal evapotranspiration (ET) of the crops by shortening time-span for ET generation. Due to dominant yield reduction over ET reduction, the water use efficiency (WUE) for grain/tuber and biomass yields would decrease with the changing climate. The reduced crop yields are an indicative of a potential future risk of food security in Bangladesh. The results of this study can therefore guide to adopt coping mechanisms in the light of climate change to ensure future food security of the country.
\end{abstract}

Keywords: climate change, DSSAT, MAGICC/SCENGEN model, CERES model, SUBSTOR model, growing season length, crop-water use

DOI: $10.25165 /$ j.ijabe.20181104.3331

Citation: Rahman A, Mojid M A, Banu S. Climate change impact assessment on three major crops in the north-central region of Bangladesh using DSSAT. Int J Agric \& Biol Eng, 2018; 11(4): 135-143.

\section{Introduction}

The current population of Bangladesh is 156 million $^{[1]}$, with one of the highest densities (1015 persons $\left./ \mathrm{km}^{2}\right)$ in the world, and the population of the country is still growing at $1.37 \%$ per year. Although this rate is expected to slow down in future, most projections estimated a 200 million population by $2050^{[2]}$. This would mean a more than $25 \%$ increase in the demand for food grains. Therefore, providing food security to its population would be a crucial socio-economic and political priority of the government of Bangladesh.

The economy of Bangladesh largely depends on agriculture, which contributes $18.7 \%$ to GDP and employs $47.3 \%$ of the labor force $^{[3]}$. Despite the increase in the shares of fisheries, livestock and forestry, crop agriculture alone accounts for $60.8 \%$ of agricultural $\mathrm{GDP}^{[4]}$. At present, nearly 10 million hectares of land is used for growing food grains. Rice being the principal grain

Received date: 2017-03-10 Accepted date: 2017-11-28

Biographies: Mohammad Abdul Mojid, PhD, Professor, research interests: soil, water, pollution, waste water, Time Domain Reflectometry (TDR), Email: ma_mojid@yahoo.com; Selina Banu, Lecturer, research interests: water management, climate change, and crop modeling, Email: selina.nit@gmail.com. *Corresponding author: Atikur Rahman, PhD, Professor, research interests: non-point source water pollution control and water quality, agricultural climatology, and crop modeling. Department of Irrigation and Water Management, Bangladesh Agricultural University, Mymensingh-2202, Bangladesh. Tel/Fax:+880-91-61510, Email: atikur.iwm@gmail.com. crop accounts for $77 \%$ of agricultural land use and contributes half of the agricultural GDP and one-sixth of the national income. Other major crops include jute $(4.74 \%)$, potato $(3.07 \%)$, vegetables $(2.45 \%)$, wheat $(2.50 \%)$ and others $(10.24 \%)^{[5]}$. Overall agricultural production in the country, since independence in 1971, has increased almost a three-fold due to adoption of modern cultivars, implementation of flood control projects, application of fertilizers and irrigation, and use of pest control and disease management practices. There remains hardly any scope for bringing new lands under cultivation, while the country is losing 80 $000 \mathrm{hm}^{2}$ of arable land every year ${ }^{[6]}$ due to housing and settlement, building physical infrastructures, river erosion and various other non-agricultural uses.

Assessment reports of the Intergovernmental Panel on Climate Change (IPCC $)^{[7]}$ and various other studies listed the potential consequences of climate change. According to those reports, combined with the potential increase in global temperature, rainfall has become variable and unpredictable, and the occurrence and strength of climate-related extreme events, such as floods, droughts, heat waves and cyclones are anticipated to increase in the future ${ }^{[7,8]}$. Taking 1990 as the base year, predictions made by IPCC $^{[9]}$ show that the average global surface temperature might increase by $1^{\circ} \mathrm{C}$ to $5^{\circ} \mathrm{C}$ by the year 2100 . In Bangladesh, temperature has been increasing for the last three decades, and it is predicted to experience an increase in average day temperature of $1^{\circ} \mathrm{C}$ by 2030 and $1.4^{\circ} \mathrm{C}$ by $2050^{[7,8]}$. Some model simulations (e.g., Agrawala et al. ${ }^{[10]}$ ) support the IPCC predictions and further forecast of 
increasing annual rainfall in Bangladesh. By analyzing historical data of 34 meteorological stations in Bangladesh for the period 1976 to 2008 , Basak et al. ${ }^{[11]}$ found an increasing rate of $0.0186^{\circ} \mathrm{C}$ and $0.0152^{\circ} \mathrm{C}$ per year for the yearly average maximum and minimum temperatures, respectively. Most models estimate that precipitation will increase, but insignificantly, during the summer monsoon and decrease in the winter months of December to February.

One of the greatest concerns of climate change is the potentially disastrous consequences on crop agriculture and food security in many parts of the world, particularly in the developing countries $^{[7,8,12-14]}$ like Bangladesh. Analyses of multiple climate change scenarios indicate that climate change will likely have a slight to moderate negative effects on crop yields ${ }^{[15,16]}$. Basak et al. ${ }^{[11]}$ investigated the effects of climate change on the yield of two Boro rice varieties at 12 locations of Bangladesh. They predicted a $20 \%$ and $50 \%$ yield reduction of both rice varieties for the years 2050 and 2070, respectively. The increase in the predicted daily maximum and minimum temperatures was found to be primarily responsible for the reduction in yield.

As Bangladesh is a most vulnerable country to climate change, the future water and food security of the country will largely depend on the impact of climate change on water demand for irrigation. However, there is an uncertainty of demand and availability of water for future food production in the country. Although the demand for food grains is expected to increase by a substantial margin, the resources like land and water needed for growing food grains would become scarcer. The growing scarcities of water and land are projected to increasingly constrain food production, causing adverse impacts on the goals for food security and human well-being ${ }^{[17]}$.

The north-central region of Bangladesh is primarily known for its leading role in agricultural productions in all sectors, including cereal grains, livestock and fisheries. Five districts of this region, Jamalpur, Sherpur, Kishoregonj, Netrokona and Mymensingh, account for $14.5 \%$ of rice, $2.83 \%$ of potato and $2.45 \%$ of wheat of the total national production ${ }^{[18]}$. The major impacts of climate change-induced erratic behavior and distribution of rainfall and rise in temperature would be on agriculture and availability of water resources for agriculture, particularly in the dry season. In the future, climate change will alter crop-water demand and, hence, the growth and yield of crops. Despite such highly susceptible climate change-induced status of the region, investigations on the potential impacts of climate change on crop-water demand and use as well as the growth and yield of various crops have been limited. A proper crop-production scenario allied with the future overall climate change scenario is crucially important for this region. Thus, this study was planned to investigate the effects of climate change on the length of growing season (LGS), evapotranspiration (ET), water-use efficiency (WUE) and yield of wheat, potato and rice with DSSAT CERES-Wheat, SUBSTOR-Potato and CERES-Rice models, respectively. The IPCC climate change projection $\mathrm{A} 2$ and $\mathrm{B} 2$ scenarios were constructed using the outputs of MAGICC/SCENGEN model in combination with observed climate data of the study region.

\section{Materials and methods}

\subsection{Study area}

The north-central region of Bangladesh is characterized by moderate temperature and rainfall compared to the average condition of the country and is full of intensive agricultural activities. The study site (Figure 1) belongs to the agro-ecological zone 9 , which lies at $24.1^{\circ}-25.2^{\circ} \mathrm{N}$ latitude and $89.67^{\circ}-91.24^{\circ} \mathrm{E}$ longitude. The soil in the study location is silt loam type with grey texture and moderately well drained. The annual temperature varies between $11.7^{\circ} \mathrm{C}$ and $31.9^{\circ} \mathrm{C}$, and the mean annual precipitation is $2490 \mathrm{~mm}$. The elevation of the site varies from 18 to $30 \mathrm{~m}$ above the mean sea level.

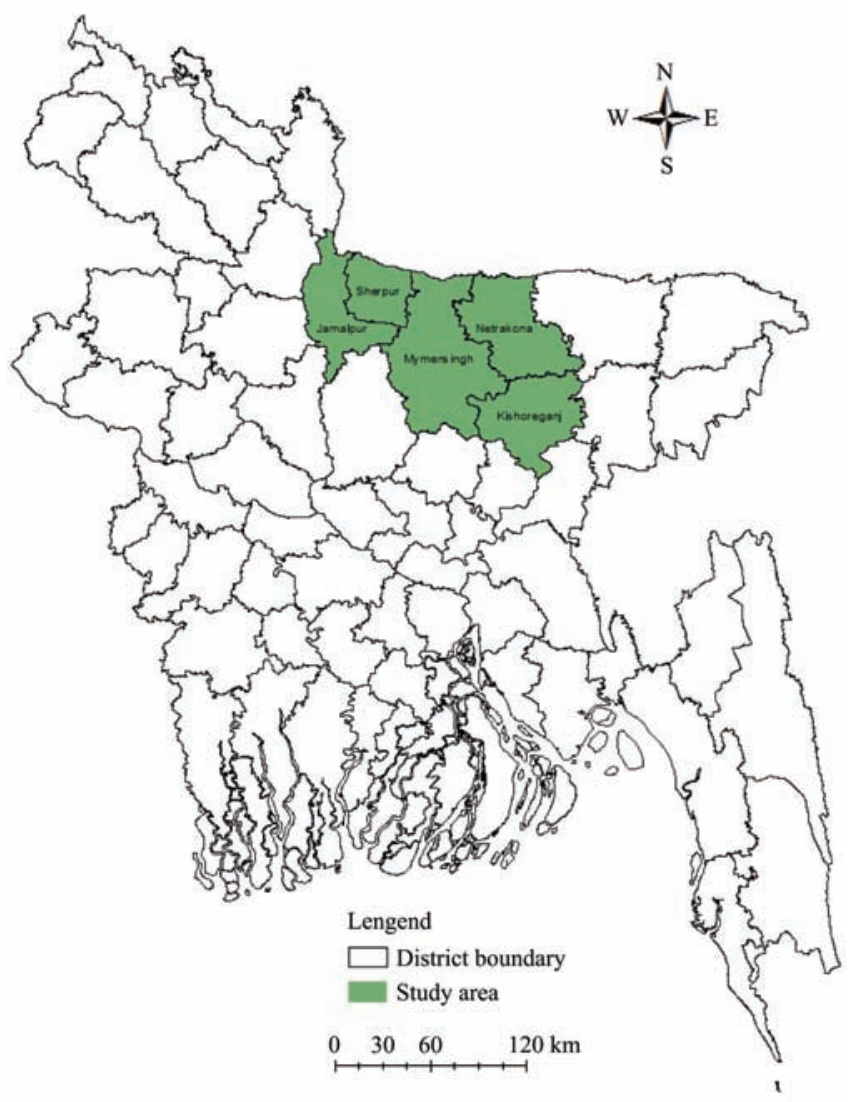

Figure 1 Map of the study area

\subsection{Data collection}

Data used for model calibration were collected from several experiments that were conducted previously in Bangladesh Agricultural University (BAU) Research Farm at Mymensingh in Bangladesh. The models used in this study required data on weather, soil, and crop growth and management.

\subsubsection{Climate data}

The climate or weather data such as the maximum and minimum temperatures, rainfall, daily solar radiation, sunshine period and wind speed of 30 years, spanning from 1985 to 2014, were collected from a weather station located at BAU Research Farm. These data constituted the baseline climate of the study.

\subsubsection{Soil data}

The texture of the experimental soil in the study area was silt loam underlain by sandy loam. The other soil data: soil profile information, nutrient status, and chemical and hydraulic properties were collected from the previous studies ${ }^{[19,20]}$. Organic matter content of the soil was low $(<1 \%$, except for rice field). The top soil was moderately acidic, but the sub-soil was neutral in reaction. The average field capacity and permanent wilting point of the soil were $39.94 \%$ and $18.70 \%$, respectively. The average bulk density was $1.33 \mathrm{~g} / \mathrm{cm}^{3}$ for the top $60 \mathrm{~cm}$ profile. The major physico-chemical properties of the soil in the crop fields are provided in Table 1. 
Table 1 Physical and chemical properties of the pre-sowing soils at different layers in wheat, potato and rice fields

\begin{tabular}{|c|c|c|c|c|c|c|c|c|c|c|}
\hline \multirow{2}{*}{ Crop } & \multirow{2}{*}{$\begin{array}{l}\text { Soil depth } \\
\text { /cm }\end{array}$} & \multicolumn{3}{|c|}{ Particle size distribution/\% } & \multirow{2}{*}{$\begin{array}{l}\text { Bulk density } \\
\quad / \mathrm{g} \cdot \mathrm{cm}^{-3}\end{array}$} & \multirow{2}{*}{ Textural class } & \multirow{2}{*}{$\begin{array}{l}\text { Field capacity } \\
\qquad / \%\end{array}$} & \multirow{2}{*}{$\begin{array}{l}\text { Wilting point } \\
\qquad / \%\end{array}$} & \multirow{2}{*}{$\mathrm{pH}$} & \multirow{2}{*}{$\begin{array}{c}\text { Organic C } \\
\qquad \%\end{array}$} \\
\hline & & sand & silt & clay & & & & & & \\
\hline \multirow{3}{*}{$\begin{array}{l}\text { Wheat and } \\
\text { potato }\end{array}$} & $0-20$ & 32.6 & 56.7 & 10.8 & 1.26 & Silt loam & 42.5 & 19.6 & 6.89 & 0.63 \\
\hline & $20-40$ & 54.6 & 40.0 & 5.43 & 1.35 & Sandy loam & 38.9 & 18.4 & 7.14 & 0.34 \\
\hline & $40-60$ & 67.9 & 26.7 & 5.42 & 1.40 & Sandy loam & 38.5 & 18.2 & 7.18 & 0.28 \\
\hline Rice & $0-20$ & 10 & 60 & 30 & 1.35 & Silty clay loam & & & 5.80 & 2.11 \\
\hline
\end{tabular}

\subsubsection{Crop growth and management data}

The crop growth and management data required for model calibration include crop phenological data, crop management data (such as amount of irrigation, irrigation method, fertilizer and harvesting), previous crop information, planting information (such as soil depth, spacing between adjacent rows, plant distribution, plant population and cultivar coefficients). The wheat and potato cultivation data for model set up were collected from the previous studies, which investigated the effects of wastewater and fertilizer application and their interactions on the crops ${ }^{[19]}$. In this study, data on the crops irrigated with only freshwater and fertilized with recommended standard doses were used for calibration and validation of the model. Data on rice cultivation were collected from a separate study, which investigated the effects of transplanting date on the yield and yield attributing characters of a Transplant Aman (T. Aman) rice variety ${ }^{[20]}$. The crop management data of wheat, potato and rice, used for model set up, are presented in Table 2. The wheat and potato crops were irrigated with 87 and $130 \mathrm{~mm}$ water, respectively, and each irrigation split into three applications. For rice, a constant water level of $6 \mathrm{~cm}$ was maintained for the entire growing season. Standard fertilizer doses for the study area recommended by the Bangladesh Agricultural Research Council ${ }^{[21]}$ were applied for all crop types studied.

Table 2 Crop management data of wheat, potato and rice

\begin{tabular}{lccc}
\hline Planting information & Wheat & Potato & Rice \\
\hline Date of planting & Dec. $12^{\text {th }}, 2007$ & Dec. $12^{\text {th }}, 2007$ & July $18^{\text {th }}, 2013$ \\
Depth of planting $/ \mathrm{cm}$ & $2-3$ & 5 & 5 \\
Row spacing $/ \mathrm{cm}$ & 20 & 60 & 15 \\
Plant population $/ \mathrm{m}^{-2}$ & - & 8 & 27 \\
Planting method & Hand rack & Furrow & Transplant \\
\hline
\end{tabular}

\subsection{Climate change scenarios generation}

Seven climate sets: a 'baseline' scenario that represents the current climatic conditions and two climate change scenarios for three future time periods were generated. The future scenarios were produced using the output from MAGIC/SCENGEN model (version 5.3) for three future time periods: (i) 2025 to 2054, centering 2040 (known as climate change scenario year 2040), (ii) 2055 to 2084, centering 2070 (known as climate change scenario year 2070) and (iii) 2085 to 2114 , centering 2100 (known as climate change scenario year 2100). For each time period, two emission scenarios, A2 (high) and B2 (medium), were simulated according to the Special Report on Emission Scenarios (SRES) ${ }^{[22]}$. The observed daily mean of the climatic data (maximum and minimum temperatures, rainfall and solar radiation) from 1984 to 2014 taken as baseline climate, were used to calculate future climatic scenarios, which were constructed together with MAGICC/SCENGEN model output using delta change approach. The SCENGEN model utilized the observed data of 1961 to 1990 from every region of the world and constituted the baseline data. In combination with the observed data, SCENGEN can generate climate scenarios for any region and time period in the $21^{\text {st }}$ century. The output of the SCENGEN model was obtained in a $2.5 \times 2.5$-degree latitude/longitude grid resolution. In this study, climatic variables predicted by this model were taken as the averages of 18 Atmosphere/Ocean GCMs (AOGCMs) to ensure that the model outputs were not biased.

The monthly outputs of the model were converted and used to construct daily climatic data for the future by the following equations:

$$
R_{d a y(a d j)}=R_{d a y}\left(1+\frac{a d j_{p c p}}{100}\right)
$$

where, $R_{\text {day }}\left[R_{\text {day (adj) }}\right]$ is the rainfall/adjusted rainfall amount falling in the study area on a given day and $\operatorname{adj}_{p c p}$ is the percentage change in rainfall.

$$
T_{a v(a d \mathrm{j})}=T_{a v}+a d j_{t m p}
$$

where, $T_{a v}$ is the daily mean temperature, ${ }^{\circ} \mathrm{C}$; $\left[T_{a v(a d j)}\right]$ is the adjusted daily mean temperature, ${ }^{\circ} \mathrm{C}$; and $a d j_{t m p}$ is the change in temperature, ${ }^{\circ} \mathrm{C}$. The daily solar radiation data was constructed from the daily maximum and minimum temperatures by employing modified Bristow-Campbell $(\mathrm{B}-\mathrm{C})$ model as described by Goodin et al. ${ }^{[23]}$.

\subsection{DSSAT model}

The Decision Support System for Agrotechnology Transfer (DSSAT) modeling system is an advanced physiologically-based crop growth simulation model, which has been applied widely to study the relationship between growth, development stages and yield of crops and their environment ${ }^{[24]}$. The inherent parts of the program include specific simulator crop models (e.g., CERES, CROPGROW, SUBSTOR, etc.) and databases for weather, soil, experimental condition and measurements, and genotype information. The crop model simulates crop yield, growth and development based on several characteristics of the crop under investigation, such as phenology, photoperiod and biomass accumulation as well as partitioning among its roots, stems and leaves, as defined by cultivar-specific genetic coefficients. The DSSAT enables the user to predict the possible results from diverse managerial dimensions and strategies through separate independent programs functioning together ${ }^{[25]}$. Among the suits of the Cropping System Model (CSM) in DSSAT, CERES-Wheat, CERES-Rice, and SUBSTOR-Potato modules were employed to study the effects of climate change on the respective crops.

\subsection{Calibration and validation of the models}

The calibration of each model was done such that the model parameters truly represented the characteristics and responses of the crops to soil and atmospheric conditions. The CERES-Wheat, CERES-Rice and SUBSTOR-Potato were calibrated using the observed data by changing one parameter at a time. The data from field experiments, conducted during 2007-2008 season, were used to calibrate CERES-Wheat and SUBSTOR-Potato models, while the data collected during $2013 \mathrm{~T}$. Aman season were used for CERES-Rice calibration. Each time, a model parameter was 
changed, and the model was run with the changed parameter value. The resulting model simulated Leaf Area Index (LAI) and yield of the crops were compared with the corresponding observed values. This process of simulation and comparison was repeated until satisfactory LAIs and yields were obtained, which were ensured by satisfactory values of the model performance indicators. Few cases during the model calibration, due to unavailability of plant phenology and plant population data, planting date and row spacing/plant population were slightly adjusted (not in each case) to match the simulated results with the observed LAIs and yields. The model calibration involved changing the values of the cultivar coefficients. The default and calibrated values of the cultivar coefficients for wheat, potato and rice are given in Table 3, 4 and 5, respectively. After calibration, CERES-Wheat and SUBSTOR-Potato models were validated using the data that were collected during 2008-2009 crop season from the same study. The CERES-Rice model was validated using the data collected in 2011 rice season from a different study ${ }^{[26]}$.

Table 3 Default and calibrated cultivar coefficients for CERES-Wheat model

\begin{tabular}{|c|c|c|c|}
\hline Parameters' code & Meaning & Default value & Calibrated value \\
\hline P1V & Days required to complete vernalization & 5 & 6 \\
\hline P1D & Percentage reduction in development rate in a photo period & 75 & 86 \\
\hline P5 & Grain filling phase duration $/{ }^{\circ} \mathrm{C} \cdot \mathrm{d}$ & 450 & 990 \\
\hline G1 & Kernel number per unit canopy weight at anthesis/\# $\mathrm{g}^{-1}$ & 30 & 49 \\
\hline G2 & Standard kernel size under optimum conditions/mg & 35 & 80 \\
\hline G3 & Standard, non-stressed dry weight of a single tiller at maturity/g & 1.0 & 2.0 \\
\hline PHINT & Interval between successive leaf tip appearances $/{ }^{\circ} \mathrm{C} \cdot \mathrm{d}$ & 60 & 100 \\
\hline
\end{tabular}

Table 4 Default and calibrated cultivar coefficients for SUBSTOR-Potato model

\begin{tabular}{clcc}
\hline Parameters' code & \multicolumn{1}{c}{ Meaning } & Default value & Calibrated value \\
\hline G2 & Leaf area expansion rate after tuber initiation $/ \mathrm{cm}^{2} \cdot \mathrm{m}^{-2} \cdot \mathrm{d}^{-1}$ & 2000 \\
G3 & Potential tuber growth rate $/ \mathrm{g} \cdot \mathrm{m}^{-2} \cdot \mathrm{d}^{-1}$ & 39 & 22 \\
G4 & Partitioning coefficient & 0.20 \\
PD & Index that suppresses tuber growth during the period that immediately follows tuber induction & 0.20 \\
P2 & Tuber initiation sensitivity to long photoperiods & 0.5 & 0.6 \\
TC & Upper critical temperature for tuber initiation $/{ }^{\circ} \mathrm{C}$ & 0.4 \\
\hline
\end{tabular}

Table 5 Default and calibrated cultivar coefficients for CERES-Rice model

\begin{tabular}{|c|c|c|c|}
\hline Parameters' code & Meaning & Default value & Calibrated value \\
\hline $\mathrm{P} 1$ & $\begin{array}{l}\text { Time period (expressed as growing degree days }[\mathrm{GDD}] \text { in }{ }^{\circ} \mathrm{C} \text { above a base temperature of } 9^{\circ} \mathrm{C} \text { ) from seedling } \\
\text { emergence during which the rice plant is not responsive to changes in photoperiod. }\end{array}$ & 740 & 750 \\
\hline $\mathrm{P} 2 \mathrm{R}$ & $\begin{array}{l}\text { Extent to which phasic development leading to panicle initiation is delayed (expressed as GDD in }{ }^{\circ} \mathrm{C} \text { ) for each } \\
\text { hour increase in photoperiod above } \mathrm{P} 2 \mathrm{O} \text {. }\end{array}$ & 180 & 200 \\
\hline P5 & $\begin{array}{l}\text { Time period in GDD }{ }^{\circ} \mathrm{C} \text { from beginning of grain filling ( } 3 \text { to } 4 \text { days after flowering) to physiological maturity } \\
\text { with a base temperature of } 9^{\circ} \mathrm{C} \text {. }\end{array}$ & 400 & 400 \\
\hline $\mathrm{P} 2 \mathrm{O}$ & Critical photoperiod or the longest day length (in hours) at which the development occurs at a maximum rate. & 10.5 & 13.5 \\
\hline G1 & $\begin{array}{l}\text { Potential spikelet number coefficient as estimated from the number of spikelets per gram of main culm dry } \\
\text { weight (less lead blades and sheaths plus spikes) at anthesis. }\end{array}$ & 55 & 70 \\
\hline $\mathrm{G} 2$ & Single grain weight (g) under ideal growing conditions. & 0.025 & 0.028 \\
\hline G3 & Tillering coefficient (scalar value) relative to IR64 cultivar under ideal conditions. & 1.0 & 1.10 \\
\hline G4 & Temperature tolerance coefficient, usually 1.0 for varieties grown in normal environments. & 0.90 & 1.50 \\
\hline
\end{tabular}

\subsection{Model performance evaluation}

Before applying the models for simulation with future climatic data, the results of calibration and validation of the models were evaluated, and the model goodness of fit was determined. Two deviation statistics, namely, root-mean square error (RMSE) and forecasting efficiency (EF), and one test statistic, called coefficient of determination $\left(R^{2}\right)$, were calculated for performance evaluation of the CERES-Wheat, SUBSTOR-Potato and CERES-Rice models. The deviation statistics were calculated by the following equations:

$$
\begin{gathered}
R M S E=\sqrt{\left[n^{-1} \sum_{i=1}^{n}\left(S_{i}-m_{i}\right)^{2}\right]} \\
E F=\frac{\sum_{i=1}^{n}\left(m_{i}-\bar{m}\right)^{2}-\sum_{i=1}^{n}\left(S_{i}-m_{i}\right)^{2}}{\sum_{i=1}^{n}\left(m_{i}-\bar{m}\right)^{2}}
\end{gathered}
$$

where, $s_{i}$ refers to the model-simulated value of a parameter; $m_{i}$ is the observed/measured value of the parameter; $n$ is the number of data points used and $\bar{m}$ is the mean value of the measured data. The RMSE measures the average of the difference between the simulated and measured values in the same unit. In case of model efficiency, an $E F$ value of unity indicates absolute correspondence between the simulated and measured data (such as, $s=m$ ), while $E F<0$ indicates that the simulated values $(s)$ are different (smaller or larger) from the measured value $(m)$. The $R^{2}$ statistic $\left(0 \leq R^{2} \leq 1\right)$ provides data variance in percentage accounted for by the model.

\subsection{Model simulation with future climate data}

The effects of climate change on the three selected crops were investigated by comparing the results of model simulation under climate change projection with the baseline. The calibrated 
models were employed to simulate crop growth and yield under future changing climatic conditions by selecting the generated future weather data as model weather inputs. Simulations were run for the baseline and three future periods of 2040, 2070 and 2100 of the projected climate change and for the two emission scenarios of B2 and A2. From the outputs of the models, yields, WUE, seasonal ET and LGS of the crops were estimated.

\section{Results and discussion}

\subsection{Baseline climate}

The mean monthly climatic parameters, calculated from the observed data over a period of 1985 to 2014, are illustrated in Figure 2. These parameter values constituted the baseline climate for this study. The mean monthly maximum and minimum temperatures were $31.9^{\circ} \mathrm{C}$ and $11.7^{\circ} \mathrm{C}$, respectively. The mean annual rainfall was $2490 \mathrm{~mm}$, which is slightly higher than the mean annual rainfall of the country $(2300 \mathrm{~mm})$. Most of the rainfalls were concentrated in the months of April to October. The mean solar radiation ranged from 14.6 to $21.5 \mathrm{MJ} /\left(\mathrm{m}^{2} \cdot \mathrm{d}\right)$. The monthly mean solar radiation was higher in the dry periods than in the rainy periods, suggesting that cloud cover obstructed solar radiation reaching the ground. The range of the monthly mean temperatures was also higher during the dry period (Figure 2)

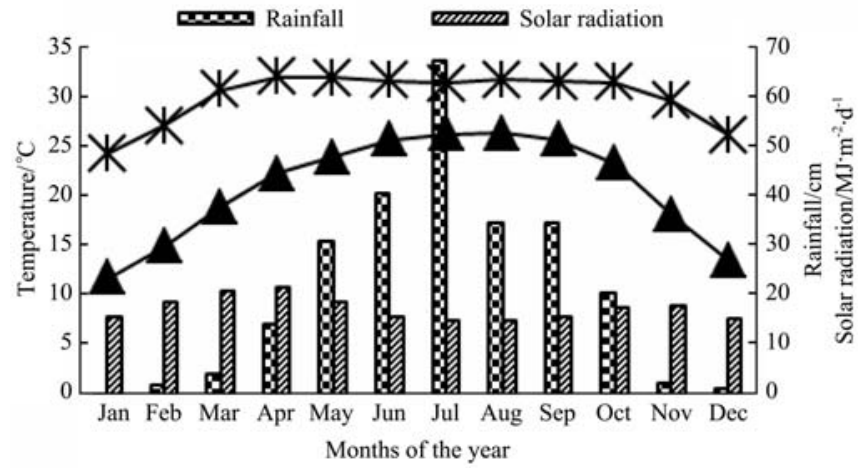

Figure 2 Mean monthly maximum and minimum temperatures, mean monthly total rainfall and mean solar radiation for the baseline period (1985-2014) in the study area

\subsection{Future climate change scenarios}

The future climate projection reveals that temperature would be gradually increasing with time in the $\mathrm{B} 2$ emission scenario; the year 2100 would have the highest increase of $2.99^{\circ} \mathrm{C}$ (Table 6). Usually, the colder months would go on larger changes than the warmer months of the year; the highest increment would be for January in 2100. The magnitude of change of temperature among the months of the year would become larger as time would elapse from the baseline to the future years of prediction. The amount of precipitation would increase or decrease in different months of the year compared to the baseline in the B2 climate change scenario (Table 6). The change of precipitation would be higher at the dryer months than the baseline climate. The highest increase of precipitation (42.2\%) would be in December of 2100. In contrast, the precipitation would decrease during April to June; the highest decrease (-12.5\%) would be in April of 2100 .

The change of temperature in 2040 would be almost similar for both $\mathrm{A} 2$ and $\mathrm{B} 2$ scenarios (Table 6). However, the predicted change of temperature would be higher in 2070 and 2100 under A2 compared to $\mathrm{B} 2$ climate change scenarios. The highest increase in temperature would be $3.29^{\circ} \mathrm{C}$ in 2070 and $5.32^{\circ} \mathrm{C}$ in 2100 in the month of January. Like B2 scenario, the variation in temperature change among the months of the year would increase in the future as the time elapses from the baseline period. Precipitation would also follow the trend of temperature variation; the highest change in precipitation was in $\mathrm{A} 2$ compared to $\mathrm{B} 2$ climate change scenario (Table 6). The precipitation would increase or decrease in different months of the future years; the highest change would occur in the year 2100. The highest increase of precipitation would be $62.2 \%$ in December of 2100 , while the highest decrease of precipitation (-18.4\%) would be in April of the same year. A similar trend of change in temperature and precipitation was observed in both scenarios but with different magnitudes.

Table 6 Increase (+ve values) or decrease (-ve values) in temperature and precipitation for the years 2040, 2070 and 2100 for $B 2$ and $A 2$ future climatic scenarios of the study area compared to their baseline values

\begin{tabular}{|c|c|c|c|c|c|c|c|}
\hline \multirow{2}{*}{ Scenario } & \multirow{2}{*}{ Month } & \multicolumn{3}{|c|}{ Change in temperature $/{ }^{\circ} \mathrm{C}$} & \multicolumn{3}{|c|}{ Change in precipitation $/ \%$} \\
\hline & & 2040 & 2070 & 2100 & 2040 & 2070 & 2100 \\
\hline \multirow{12}{*}{ B2 } & January & 1.53 & 2.58 & 3.63 & 10.5 & 17.8 & 24.9 \\
\hline & February & 1.39 & 2.35 & 3.30 & 11.2 & 19.0 & 26.6 \\
\hline & March & 1.31 & 2.21 & 3.10 & 5.7 & 9.6 & 13.5 \\
\hline & April & 1.29 & 2.17 & 3.05 & -5.3 & -8.9 & -12.5 \\
\hline & May & 1.29 & 2.18 & 3.07 & -3.2 & -5.4 & -7.6 \\
\hline & June & 1.21 & 2.04 & 2.86 & -0.60 & -1.0 & -1.4 \\
\hline & July & 1.12 & 1.90 & 2.67 & 1.2 & 2.0 & 2.8 \\
\hline & August & 1.22 & 2.06 & 2.90 & 1.3 & 2.2 & 3.1 \\
\hline & September & 1.30 & 2.19 & 3.08 & 1.7 & 2.9 & 4.1 \\
\hline & October & 1.06 & 1.79 & 2.51 & 5.6 & 9.4 & 13.2 \\
\hline & November & 1.28 & 2.16 & 3.04 & 9.0 & 15.1 & 21.3 \\
\hline & December & 1.26 & 2.13 & 2.99 & 9.2 & 30.2 & 42.4 \\
\hline \multirow{12}{*}{$\mathrm{A} 2$} & January & 1.59 & 3.29 & 5.32 & 10.9 & 22.6 & 36.6 \\
\hline & February & 1.59 & 3.0 & 4.84 & 11.7 & 24.2 & 39.1 \\
\hline & March & 1.36 & 2.82 & 4.55 & 5.9 & 12.3 & 19.9 \\
\hline & April & 1.34 & 2.77 & 4.48 & -5.5 & -11.4 & -18.4 \\
\hline & May & 1.34 & 2.78 & 4.50 & -3.3 & -6.9 & -11.1 \\
\hline & June & 1.24 & 2.60 & 4.20 & -0.6 & -1.2 & -2.0 \\
\hline & July & 1.17 & 2.42 & 3.91 & 1.2 & 2.6 & 4.1 \\
\hline & August & 1.27 & 2.63 & 4.25 & 1.3 & 2.8 & 4.5 \\
\hline & September & 1.35 & 2.37 & 4.52 & 1.8 & 3.7 & 6.0 \\
\hline & October & 1.10 & 2.28 & 3.69 & 5.8 & 12.0 & 19.4 \\
\hline & November & 1.33 & 2.76 & 4.46 & 9.3 & 19.3 & 31.2 \\
\hline & December & 1.31 & 2.72 & 4.39 & 18.6 & 38.5 & 62.2 \\
\hline
\end{tabular}

\subsection{Model calibration and validation}

The CERES-Wheat, CERES-Rice and SUBSTOR-Potato models were calibrated and validated for crop yield and LAI and the results are presented in Figure 3 and Table 7. The prediction of crop yields in the validation period was in close agreement with the observed yields for all three crops under investigation (Figure 3). The simulated yield in the calibration phase was $4.12,16.8$ and $5.6 \mathrm{t} / \mathrm{hm}^{2}$ for wheat, potato and rice, respectively against the observed corresponding yields of $4.11,16.3$ and $5.5 \mathrm{t} / \mathrm{hm}^{2}$.

The CERES-Wheat model was calibrated well for LAI with $R^{2}$ of 0.72 , RMSE of $0.28 \mathrm{t} / \mathrm{hm}^{2}$ and EF of 0.78 (Table 7). The performance of SUBSTOR-Potato model for LAI prediction was satisfactory as indicated by large value of $R^{2}$ and small deviation statistics (Table 7); the values of $R^{2}$, RMSE and EF were obtained 
as $0.71,0.29 \mathrm{t} / \mathrm{hm}^{2}$ and 0.45 , respectively during calibration. For CERES-Rice, $R^{2}$ was 0.87 and EF was 0.74 , indicating a strong correlation between the simulated and observed LAIs. The calibrated models performed well during validation for LAI as indicated by the obtained $R^{2}$, RMSE and EF. However, prediction of LAI for rice during model validation was not as good as the other two models; the poor performance of the model was indicated by higher RMSE and negative EF values.

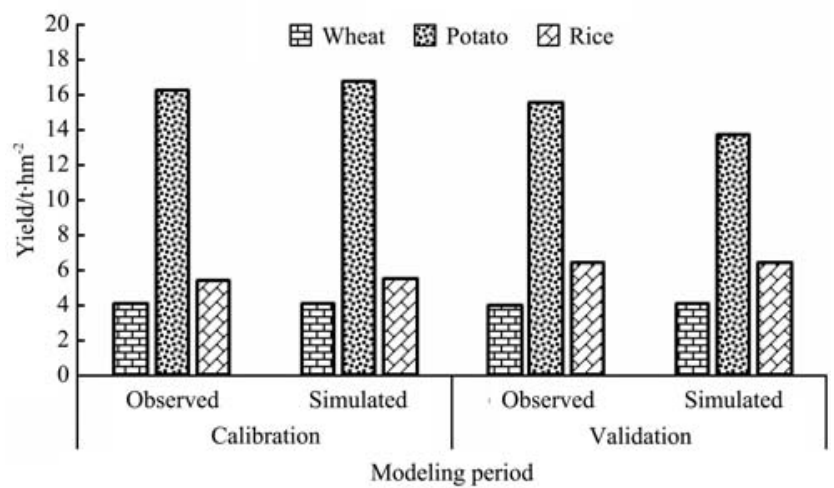

Figure 3 Simulated and observed grain yield of wheat, potato and rice during model calibration

Table 7 Coefficient of determination $\left(R^{2}\right)$, root-mean square error (RMSE) and model efficiency (EF) in simulating leaf area index (LAI) during calibration of CERES-Wheat, CERES-Rice and SUBSTOR-Potato models

\begin{tabular}{|c|c|c|c|c|c|c|c|c|c|}
\hline & \multicolumn{9}{|c|}{ Performance parameters for } \\
\hline & \multicolumn{3}{|c|}{ Wheat } & \multicolumn{3}{|c|}{ Potato } & \multicolumn{3}{|c|}{ Rice } \\
\hline & $R^{2}$ & $\begin{array}{l}\text { RMSE } \\
/ \mathrm{t} \cdot \mathrm{hm}^{-2}\end{array}$ & $\mathrm{EF}$ & $R^{2}$ & $\begin{array}{l}\mathrm{RMSE} \\
/ \mathrm{t} \cdot \mathrm{hm}^{-2}\end{array}$ & $\mathrm{EF}$ & $R^{2}$ & $\begin{array}{l}\mathrm{RMSE} \\
/ \mathrm{t} \cdot \mathrm{hm}^{-2}\end{array}$ & $\mathrm{EF}$ \\
\hline Calibration & 0.72 & 0.28 & 0.78 & 0.71 & 0.29 & 0.45 & 0.87 & 0.83 & 0.74 \\
\hline Validation & 0.93 & 0.28 & 0.76 & 0.77 & 0.74 & 0.27 & 0.97 & 2.31 & -0.32 \\
\hline
\end{tabular}

\subsection{Impact of climate change on wheat, potato and rice}

\subsubsection{Yield}

The simulated yields of wheat, potato and rice gradually decreased in both emission scenarios (A2 and B2) as time elapsed from the baseline to the future years of prediction (Figure 4). For all three crop types, decrease in yield was higher in A2 scenario compared to B2 scenario, revealing the negative impacts of increased temperature and changes in precipitation on the yield. The simulated wheat yield ranged from 2.16 to $3.69 \mathrm{t} / \mathrm{hm}^{2}$ in $\mathrm{A} 2$ scenario and from 2.64 to $3.72 \mathrm{t} / \mathrm{hm}^{2}$ in B2 scenario; the simulated yield was the lowest in 2100 . The predicted potato yield ranged from 10.4 to $11.2 \mathrm{t} / \mathrm{hm}^{2}$ for A2 scenario and from 11.2-11.5 t/ $/ \mathrm{hm}^{2}$ in B2 scenario. In B2 scenario, potato yield increased with time after an initial decrease from the baseline; the simulated yield was the lowest in 2070. The yield decrease was also simulated for rice, and the lowest predicted yield was $2.52 \mathrm{t} / \mathrm{hm}^{2}$ for B2 and $1.80 \mathrm{t} / \mathrm{hm}^{2}$ for A2 scenario in 2100 .

The simulated wheat yield started decreasing more drastically in scenario A2 after 2040 compared to scenario B2 (Table 8). The highest yield reduction was $35.9 \%$ and $47.6 \%$ in $\mathrm{B} 2$ and $\mathrm{A} 2$ scenario, respectively in the year 2100 . The highest reduction in potato yield, with respect to baseline, was $38.5 \%$ for A2 scenario in 2100 and $33.6 \%$ for $\mathrm{B} 2$ scenario in 2070 . The highest reductions in potato yield due to climate change reported to be $40 \%$ in Idaho and $50 \%$ in Nebraska ${ }^{[27]}$ are in close agreement with our findings. The yield reduction due to climate change was the highest for rice, simulating $67.8 \%$ reduction in A2 scenario and $55.2 \%$ reduction in B2 scenario in 2100 compared to the baseline yield. Several studies investigating climate change impact on rice production also reported yield reduction, which compared well with our results. Due to climate change, Basak et al. ${ }^{[1]}$ predicted a $57 \%$ yield reduction of Boro rice for the year 2070 for Mymensingh region, while Iqbal ${ }^{[28]}$ reported a $61.3 \%$ yield reduction of Aman rice for the year 2050 for Rangpur district. Climate change affects the physiology of the rice crop that occurs, mainly, from increased temperature ${ }^{[29]}$. However, the overall impact on rice yield depends on the combined effects of various climatic parameters, including temperature ${ }^{[30]}$. Likewise, the yield reduction of wheat, potato and rice was attributed to the change of climatic parameters, in which the precipitation and temperature have gone a major change in both $\mathrm{A} 2$ and $\mathrm{B} 2$ scenarios. The predicted change in temperature and precipitation affected the crop yields by hastening plant development, altering water and nutrient budget in the field and modifying plant stress ${ }^{[31,32]}$

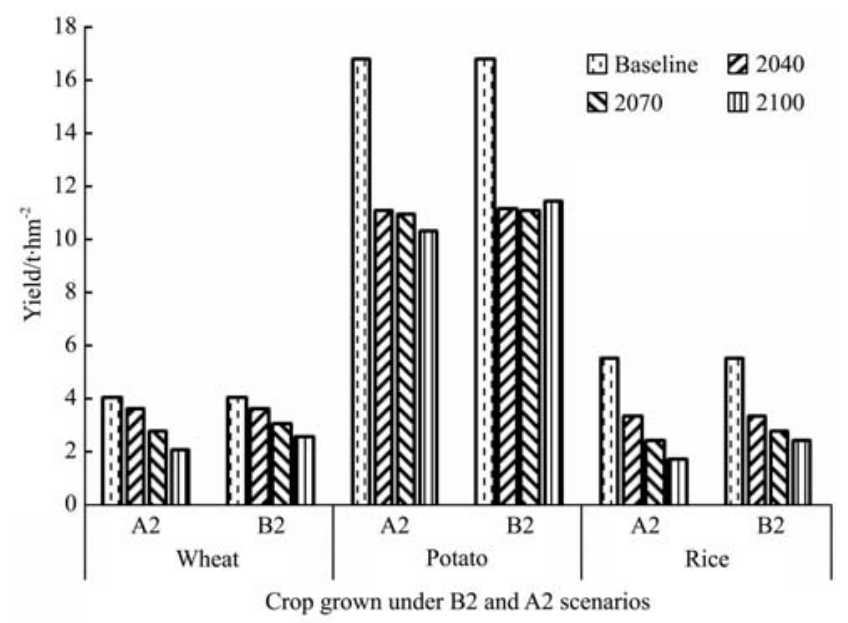

Figure 4 Predicted yield of wheat, potato and rice at baseline and three future years of projected climatic change

Table 8 Simulated yield reduction (\%) of wheat, potato and rice in the future years due to climate change under $\mathrm{B} 2$ and $\mathrm{A2}$ scenarios compared to the baseline climate

\begin{tabular}{ccccccccc}
\hline \multirow{2}{*}{ Year } & \multicolumn{2}{c}{ Wheat } & & \multicolumn{2}{c}{ Potato } & & \multicolumn{2}{c}{ Rice } \\
\cline { 2 - 5 } \cline { 6 - 8 } & B2 & A2 & & B2 & A2 & & B2 & A2 \\
\hline 2040 & 9.79 & 10.5 & 33.6 & 33.6 & 39.7 & 39.9 \\
2070 & 23.8 & 31.8 & 33.6 & 34.7 & & 49.1 & 55.5 \\
2100 & 35.9 & 47.6 & 31.6 & 38.5 & & 55.2 & 67.8 \\
\hline
\end{tabular}

\subsubsection{Water use efficiency}

Water use efficiency, WUE, calculated as the ratio of yield to total water used, for biomass production in wheat would increase in 2040 compared to the baseline WUE, but would decrease thereafter due to climate change (Figure 5a). The predicted highest WUE for biomass production was $302 \mathrm{~kg} /\left(\mathrm{hm}^{2} \cdot \mathrm{cm}\right)$ and $303 \mathrm{~kg} /\left(\mathrm{hm}^{2} \cdot \mathrm{cm}\right)$ in $\mathrm{A} 2$ and B2 scenario, respectively in 2040. The lowest biomass-WUE was $233 \mathrm{~kg} /\left(\mathrm{hm}^{2} \cdot \mathrm{cm}\right)$ and $260 \mathrm{~kg} /\left(\mathrm{hm}^{2} \cdot \mathrm{cm}\right)$ in A2 and B2 scenarios, respectively in 2100 . The simulated WUE for grain production was lower than the biomass-WUE, but it followed the trend similar to that of biomass-WUE. The WUE would increase in 2040 but decrease in 2100. The predicted grain-WUE ranged from 119 to $186 \mathrm{~kg} /\left(\mathrm{hm}^{2} \cdot \mathrm{cm}\right)$ in A2 scenario and from $140-185 \mathrm{~kg} /\left(\mathrm{hm}^{2} \cdot \mathrm{cm}\right)$ in B2 scenario. Although WUE depends on water balance 
components and, consequently, varies with location and time slice $^{[33]}$, the reduced WUE obtained in this study compared well with published results of other similar studies ${ }^{[34]}$. However, due to the likely occurrence of temperature and precipitation in appropriate proportions resulting from climate change, the WUE, compared to baseline, would increase in 2040. Temperaturemediated increase in wheat WUE was also observed by Guo et al. ${ }^{[34]}$ in a similar study on climate change in China.
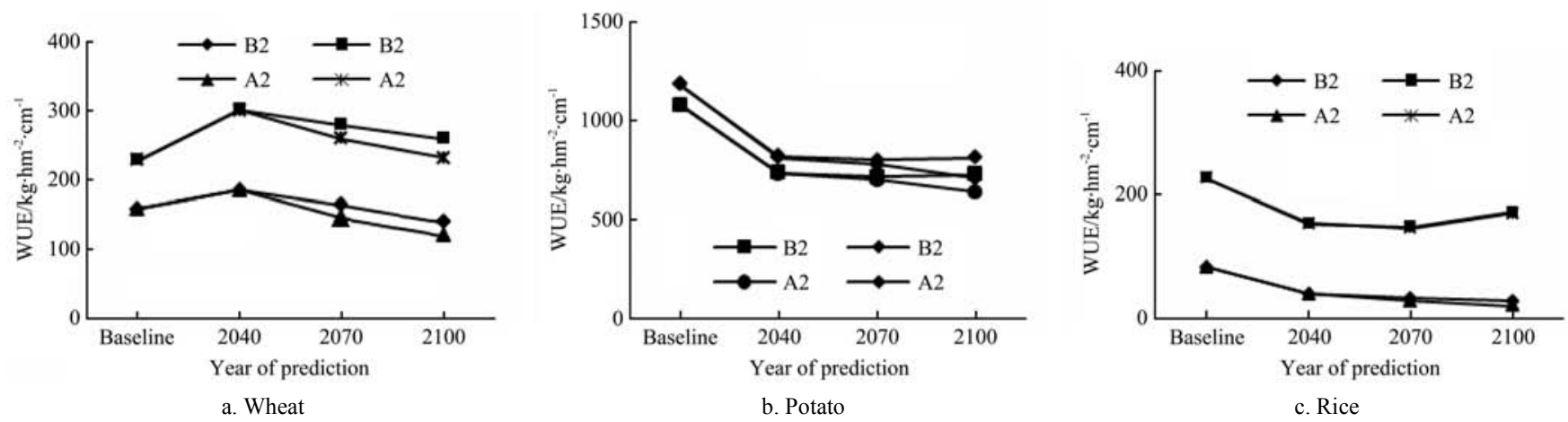

Figure 5 Predicted water use efficiency (WUE) for biomass and grain/tuber production of (a) wheat, (b) potato and (c) rice at baseline and three future years $(2040,2070$ and 2100) under projected climate change for B2 and A2 scenarios

The simulated WUE for biomass and tuber production of potato at baseline was $1185 \mathrm{~kg} /\left(\mathrm{hm}^{2} \cdot \mathrm{cm}\right)$ and $1081 \mathrm{~kg} /\left(\mathrm{hm}^{2} \cdot \mathrm{cm}\right)$, respectively in B2 scenario, and $1183 \mathrm{~kg} /\left(\mathrm{hm}^{2} \cdot \mathrm{cm}\right)$ and 1080 $\mathrm{kg} /\left(\mathrm{hm}^{2} \cdot \mathrm{cm}\right)$, respectively in A2 scenario. WUE would decrease in the future years due to projected climate change in both scenarios (Figure 5b). The lowest WUE for biomass and tuber production in A2 scenario was $706 \mathrm{~kg} /\left(\mathrm{hm}^{2} \cdot \mathrm{cm}\right)$ and $637 \mathrm{~kg} /\left(\mathrm{hm}^{2} \cdot \mathrm{cm}\right)$, respectively. The corresponding quantity in B2 scenario was $798 \mathrm{~kg} /\left(\mathrm{hm}^{2} \cdot \mathrm{cm}\right)$ and $716 \mathrm{~kg} /\left(\mathrm{hm}^{2} \cdot \mathrm{cm}\right)$ for the year 2070. The decrease in WUE was attributed to the decrease in biomass and tuber production, and increase in total water use.

Rice biomass-WUE dropped abruptly in 2040 and continued to drop until 2070, but it regained in 2100 for both scenarios (Figure 5c). The lowest biomass-WUE was $146 \mathrm{~kg} /\left(\mathrm{hm}^{2} \cdot \mathrm{cm}\right)$ in $\mathrm{A} 2$ scenario and $148 \mathrm{~kg} /\left(\mathrm{hm}^{2} \cdot \mathrm{cm}\right)$ in B2 scenario in 2070 . On the contrary, no increase of WUE for grain production was observed after initial drop from the baseline. The baseline WUE for grain production was $82.3 \mathrm{~kg} /\left(\mathrm{hm}^{2} \cdot \mathrm{cm}\right)$ in both B2 and A2 scenarios, but it decreased in the future years due to climate change. The lowest WUE for grain production, obtained for the year 2100, was $27.6 \mathrm{~kg} /\left(\mathrm{hm}^{2} \cdot \mathrm{cm}\right)$ in B2 scenario and $19.1 \mathrm{~kg} /\left(\mathrm{hm}^{2} \cdot \mathrm{cm}\right)$ in $\mathrm{A} 2$ scenario. The WUE decreased, likely, due to the change of climatic parameters (e.g., increasing precipitation), and soil and crop management practices that would influence water balance for cultivation of the crops ${ }^{[33]}$.

\subsubsection{Length of growing season}

The length of growing season, LGS, for the three crops under investigation decreased from the baseline to the future years due to the predicted climate change under both A2 and B2 scenarios (Figure 6). The LGS of wheat would be $119 \mathrm{~d}$ at baseline climate but would reduce to $97 \mathrm{~d}$ in A2 scenario and $103 \mathrm{~d}$ in B2 scenario in 2100. However, the LGS of potato would not change considerably in that period. The simulated LGS at baseline would be $84 \mathrm{~d}$ in both $\mathrm{A} 2$ and $\mathrm{B} 2$ scenarios and would reduce to $83 \mathrm{~d}$ for both scenarios in all future years under prediction. The LGS of rice would decrease gradually from $147 \mathrm{~d}$ at baseline to $131 \mathrm{~d}$ and $129 \mathrm{~d}$ for B2 and A2 scenario, respectively. Changes in temperature and solar radiation substantially affect physiological maturity of the crops. Consequently, these climatic parameters would accelerate crop development and maturity, and, thereby, reduce the $\operatorname{LGS}^{[11,34,35]}$. Planting date also has an effect on physiological maturity of a crop; delayed planting may reduce physiological maturity or $\mathrm{LGS}^{[35]}$. However, accelerated crop development due to increased temperature reduces LGS for which there may not have enough time for effective grain filling that, ultimately, results in reduced yield ${ }^{[37]}$.

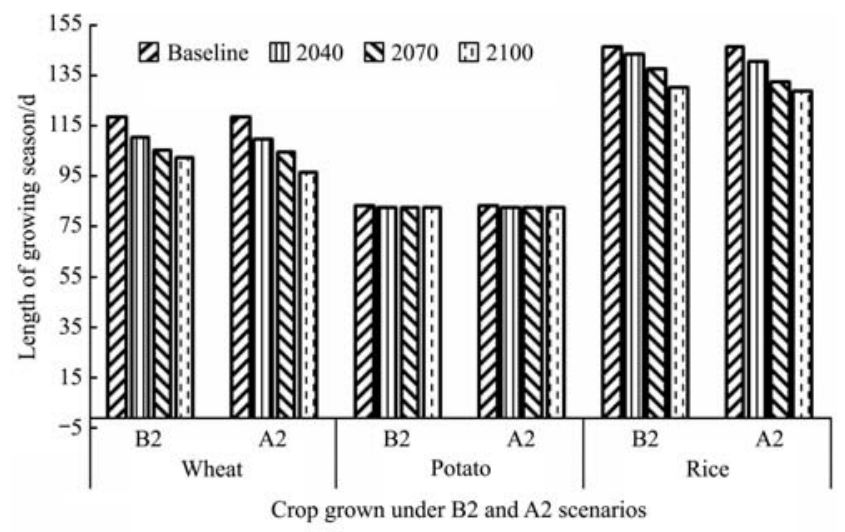

Figure 6 Simulated length of growing season of wheat at baseline and in the year 2040, 2070 and 2100 under projected climate change for $\mathrm{B} 2$ and $\mathrm{A} 2$ scenarios

\subsubsection{Seasonal crop evapotranspiration}

Simulated evapotranspiration, ET, of the three crop types under investigation decreased from the baseline to the future years due to projected climate change. The reduction of ET over time was linear for wheat, but non-linear for potato and rice (Figure 7). After an initial drop of ET from the baseline in 2040, the reduction of ET was only minor for potato and rice (Figures $7 \mathrm{~b}$ and $7 \mathrm{c}$ ). At baseline, the simulated ET of potato was $425.1 \mathrm{~mm}$ in both A2 and B2 scenarios that decreased to $272.4 \mathrm{~mm}$ and $279.8 \mathrm{~mm}$ in B2 and A2 scenario, respectively in 2100 . ET of rice at baseline was $1001 \mathrm{~mm}$ and dropped abruptly to $595 \mathrm{~mm}$ in B2 and $591 \mathrm{~mm}$ in A2 scenario in 2040. However, the decrease in ET was very small after 2040; the lowest ET was $577 \mathrm{~mm}$ in B2 and $581 \mathrm{~mm}$ at A2 in 2100. ET depends on both climatic and non-climatic variables, such as precipitation, temperature, sunshine, wind speed, soil porosity, land slope, crop variety, etc. ${ }^{[1]}$. In this study, the climatic factors in combination with LGS were the main drivers for decreasing ET; the shorter LGS reduced the time for ET generation and, consequently, resulted in reduced ET. The observed reduction of ET agreed well with a climate change study done in some parts of China ${ }^{[34]}$, where the rise of temperature and $\mathrm{CO}_{2}$ level were reported to contribute in reducing ET. 

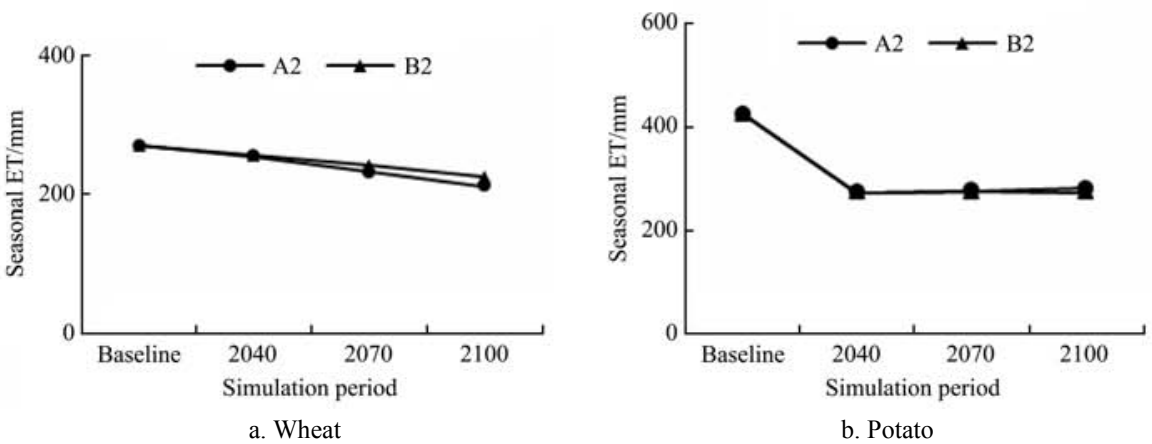

b. Potato

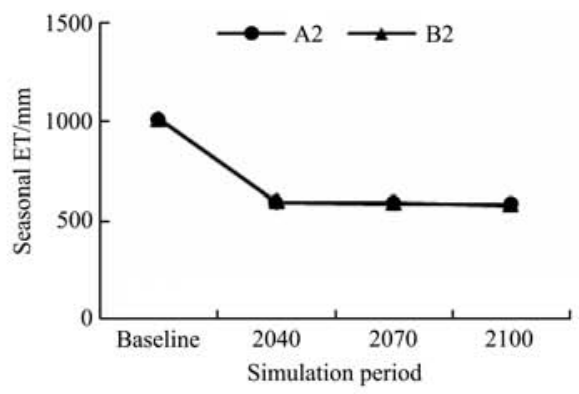

c. Rice

Figure 7 Simulated evapotranspiration (ET) of (a) wheat, (b) potato and (c) rice at baseline and in the year 2040, 2070 and 2100 under projected climate change for $\mathrm{B} 2$ and $\mathrm{A} 2$ scenarios

\section{Conclusions}

Due to climate change, temperature of the north-central Bangladesh would increase progressively from the baseline (observed mean of the climatic data of 1984 to 2014) to the year 2100 for the IPCC climate change scenarios A2 and B2. The predicted highest increase in temperature is $3.62^{\circ} \mathrm{C}$ in $\mathrm{B} 2$ and $5.32^{\circ} \mathrm{C}$ in $\mathrm{A} 2$ scenario in 2100 . Precipitation would also increase, except in the months of April to June; the increase would be higher during October to February than in the other months. The predicted climate change would exert enormous effects on crop production in the region. The $5.32^{\circ} \mathrm{C}$ increase in temperature would cause yield reduction of wheat, rice and potato by $47.6 \%$, $67.8 \%$ and $38.6 \%$, respectively. The increased temperature would reduce LGS of the crops by accelerating their physiological maturity, especially for rice and wheat, with a consequent reduction in seasonal ET of the crops. But, because of dominant yield reduction over the ET reduction, WUE would decrease for both the grain/tuber and biomass yields for wheat and potato, but only for grain yield for rice. The predicted crop yield reduction exposes a potential risk for food security in Bangladesh in the verge of increasing population and diminishing crop lands. Therefore, the results of this study, as well as of similar others, need to be considered as guidelines for a better planning, such as changing the current cropping practices or developing new varieties, to adopt climate change coping mechanisms to safeguard future food security of the country.

\section{[References]}

[1] BBS (Bangladesh Bureau of Statistics). Yearbook of agricultural statistics of Bangladesh. Dhaka, Bangladesh: Statistics Division, Ministry of Planning, Government of the People's Republic of Bangladesh, 2014.

[2] BBS (Bangladesh Bureau of Statistics). Yearbook of agricultural statistics of Bangladesh. Dhaka, Bangladesh: Statistics Division, Ministry of Planning, Government of the People's Republic of Bangladesh, 2001.

[3] BBS (Bangladesh Bureau of Statistics). Yearbook of agricultural statistics of Bangladesh, Dhaka, Bangladesh: Statistics Division, Ministry of Planning, Government of the People's Republic of Bangladesh, 2012-2013.

[4] BBS (Bangladesh Bureau of Statistics). Statistical pocket book of Bangladesh. Dhaka, Bangladesh: Ministry of Planning, Government of the People's Republic of Bangladesh, 2008.

[5] BBS (Bangladesh Bureau of Statistics). Yearbook of Agricultural Statistics of Bangladesh. Dhaka, Bangladesh: Statistics Division, Ministry of Planning, Government of the People's Republic of Bangladesh, 2010-2011.

[6] Mondal M H. Crop agriculture of Bangladesh: challenges and opportunities. Bangladesh J. Agric. Res., 2010; 235-245.
[7] IPCC (Intergovernmental Panel on Climate Change). Summary for policymakers, in: Solomon S, Qin D, Manning M, Chen Z, Marquis M, Averyt K B, Tignor M, Miller H L (Eds.), editors. Climate change, 2007: The physical science basis. Contribution of working group I to the fourth assessment report of the Intergovernmental Panel on Climate Change. Cambridge, United Kingdom and New York, NY, USA: Cambridge University Press, 2007.

[8] FAO (Food and Agriculture Organization). Adaptation to climate change in agriculture, forestry and fisheries: perspective, framework and priorities. Rome, Italy: Food and Agriculture Organization, 2007.

[9] IPCC (Intergovernmental Panel on Climate Change). Climate change 2001: impacts, adaptation and vulnerability. Contribution of working group II to the third assessment report of the Intergovernmental Panel on Climate Change. Cambridge, U.K.: Cambridge University Press, 2001.

[10] Agrawala S, Ota T, Ahmed AU, Smith J, Aalst M. Development and climate change in Bangladesh: focus on coastal flooding and the sundarbans. Paris, France: OECD, 2003.

[11] Basak J K, Ali M A, Islam M N, Rashid M A. Assessment of the effect of climate change on boro rice production in Bangladesh using DSSAT model. J. Civil Eng. 2010; 38: 95-108.

[12] Mertz O, Halsnaes K, Olesen J, Rasmussen K. Adaptation to Climate Change in Developing Countries. Environ. Manage, 2009; 43(5): $743-752$.

[13] Roudier P, Sultan B, Quirion P, Berg A. The impact of future climate change on West African crop yields: What does the recent literature say? Global Environmental Change-Human and Policy Dimensions, 2011; 21(3): 1073-1083.

[14] WB (World Bank). World development report. Washington, DC: The World Bank, 2010.

[15] Cline W R. Global warming and agriculture: impact estimates by country. Washington, DC: Cent. Global Dev, 2007.

[16] Parry M, Rosenzweig C, Iglesias A, Livermore M, Fischer G. Effects of climate change on global food production under SRES emissions and socio-economic scenarios. Global Environmental Change-Human and Policy Dimensions, 2004; 14(1): 53-67.

[17] Rosegrant M W, Cai X, Cline S A. World water and food to 2025: dealing with scarcity. Washington, DC/Sri Lanka: Int. Water Manage. Inst, 2002.

[18] BBS (Bangladesh Bureau of Statistics). Yearbook of agricultural statistics of Bangladesh, Dhaka, Bangladesh: Statistics Division, Ministry of Planning, Government of the People's Republic of Bangladesh, 2011.

[19] Biswas S K. Effects of irrigation with municipal wastewater on wheat and potato cultivation. Ph.D. Dissertation. Mymensingh: Department of Irrigation and Water Management, Bangladesh Agricultural University, 2012.

[20] Reza S N. Growth, yield and grain dimensions of T. Aman rice varieties as influenced by date of transplanting. MS Thesis. Mymensingh: Department of Agronomy, Bangladesh Agricultural University, 2014.

[21] BARC (Bangladesh Agricultural Research Council). Soil fertility status of different agro-ecological zones. Dhaka: Bangladesh Agricultural Research Council, 2005. pp.15-32.

[22] IPCC (Intergovernmental Panel on Climate Change). Special report on emissions scenarios (SRES), in: Nakicenovic N, Swart R. (Eds.). Summary for policymakers. Geneva, Switzerland: Cambridge University Press, 2000; p. 20

[23] Goodin D, Hutchinson J, Vanderlip R, Knapp M. Estimating solar 
irradiance for crop modeling using daily air temperature data. Agron. J., 1999; 91(5): 845-851.

[24] Tsuji G Y, Uehara G, Balas S. DSSAT: A decision support system for agrotechnology transfer. Honolulu, Hawaii, USA: University of Hawaii, 1994.

[25] Jones J, Hoogenboom G, Porter C, Boote K, Batchelor W, Hunt L, Wilkens P, Singh U, Gijsman A, Ritchie J. The DSSAT cropping system model. Eu. J. Agron., 2003; 18(3-4): 235-265.

[26] Mojid M A, Wyseure G. Fertility aspects of municipal wastewater on rice cultivation and soil health in Bangladesh. In "Fertilizers technology II: biofertilizers". Shishir S, Pant K K, Bajpc S, Govil J N. (Eds.). Studiurn Press LLC, USA, 2015; pp.410-423.

[27] Tubiello F, Rosenzweig C, Goldberg R, Jagtap S, Jones J. Effects of climate change on US crop production: simulation results using two different GCM scenarios. Part I: wheat, potato, maize, and citrus. Clim. Res., 2002; 20(3): 259-270.

[28] Iqbal M M. Assessment of food and water security in south-asia under changing climate scenario using crop simulation and water management models, and identification of appropriate strategies to meet future demands. Kobe, Japan: APN, 2008.

[29] Tripathi A, Tripathi D, Chauhan D, Kumar N, Singh G. Paradigms of climate change impacts on some major food sources of the world: a review on current knowledge and future prospects. Agric. Ecosyst. Environ, 2016; 216: 356-373.
[30] Zhang S, Tao F, Zhang Z. Changes in extreme temperatures and their impacts on rice yields in southern China from 1981 to 2009, Field Crop. Res, 2016; 189: 43-50.

[31] Long S. Modification of the response of photosynthetic productivity to rising temperature by atmospheric $\mathrm{CO}_{2}$ concentrations - has its importance been underestimated? Plant Cell Environ, 1991; 14(8): 729-739.

[32] Tubiello F, Rosenzweig C, Kimball B, Pinter P, Wall G, Hunsaker D, LaMorte R, Garcia R. Testing CERES-wheat with free-air carbon dioxide enrichment (FACE) experiment data: $\mathrm{CO}_{2}$ and water interactions. Agron. J., 1999; 91(2): 247-255.

[33] Jalota S, Vashisht B, Kaur H, Kaur S, Kaur P. Location specific climate change scenario and its impact on rice and wheat in Central Indian Punjab. Agric. Syst., 2014; 131: 77-86.

[34] Guo R, Lin Z, Mo X, Yang C. Responses of crop yield and water use efficiency to climate change in the North China Plain. Agric. Water Manage, 2010; 97(8): 1185-1194.

[35] Tao F, Yokozawa M, Xu Y, Hayashi Y, Zhang Z. Climate changes and trends in phenology and yields of field crops in China, 1981-2000. Agric Forest Meteorol, 2006; 138(1-4): 82-92.

[36] Basak J K. Effects of climate change on Boro cultivation in Bangladesh. MS Thesis. Dhaka: Department of Civil Engineering, Bangladesh University of Engineering and Technology, 2009.

[37] Menzel A. Plant phenological anomalies in Germany and their relation to air temperature and NAO. Clim. Change, 2003; 57(3): 243-263. 